\title{
Fuelwood extraction by indigenous, rural and urban poors do not risk trees and forest: a case study from Jharkhand, India
}

\begin{abstract}
Wood biomass from forest is the major source of domestic energy in most of the developing countries. The present study was an attempt to document information on wood collection, consumption and species used for domestic energy needs by residents of both rural and urban villages in Ranchi district of Jharkhand state, India in different seasons round the year. Wood fuel is the major domestic fuel in the study area which is mainly collected from forests or non-forest lands or purchased. The fuel need is also supplemented by coal in urban localities. The consumption of wood and coal in both urban and rural areas increases during winter and gradually decreases from rainy to summer season. The quantity of wood consumption per family in study area varied from $2.5-6.5 \mathrm{Kg} /$ day in urban areas while it was $6.0-12.0 \mathrm{Kg} /$ day in rural areas. The wood of species Mangifera indica, Syzigium cumini, Gmelina arborea, Madhuca indica and Dalbergia sissoo were found mostly used for domestic energy purposes because of their availability. Firewood extraction by indigenous, rural and urban poor in our study area are no way causing loss to forest or threatening tree species to risk as they are using dead stems, twigs or branches of trees either from non-forest lands or from forest those species which are in lesser priority list of IUCN (International Union for Conservation of Nature). Instead, there should be capacity built for involvement of urban poor in more and more afforestation/reforestation programmes of multipurpose species in non-forest lands and their rights safeguarded so that they can also use firewood solely for their domestic energy need and not supplement hydrocarbon fossils like coal.
\end{abstract}

Keywords: fuel wood, forest, energy, coal, cow dung, crop residue, timber species, forest vegetation, climate change, wildlife, bioenergy, afforestation, harvest and replant, environmental footprints, firewood
Volume 2 Issue 3 - 2018

\author{
Gopal Shukla,' Anjali Kumari, ${ }^{2}$ Abha Manohar \\ K,' 'Vineeta,' Sumit Chakravarty' \\ 'Department of Forestry, University in Cooch Behar, India \\ ${ }^{2}$ Department of Botany, Ranchi University, India
}

\begin{abstract}
Correspondence: Gopal Shukla, Department of Forestry, Uttar Banga Krishi Viswavidyalaya, University in Cooch Behar, Pundibari-736165, West Bengal, India Tel +91-985I380707, Email gopalshuklal2@gmail.com
\end{abstract}

Received: January 21, 2018 | Published: June 15, 2018

\section{Introduction}

During the past few decades, India has experienced many changes in its energy consumption pattern both in qualitative and quantitative terms. ${ }^{1}$ This is mainly due to rising population growth and increase of economic and developmental activity. The household sectors is one of the largest users of energy in India, accounting for about $30 \%$ of final energy consumption (excluding energy used for transport) reflecting the importance of the sector in total national energy scenario. ${ }^{2}$ The pattern of household energy consumption represents the status of welfare as well as the stage of economic development. International Energy Agency predicts that population growth will render 2.7 million people relying on plant base energy forms in the year $2030 .{ }^{1}$ The rural and urban poor population mainly depend on plant biomass resources (cow dung, crop residue, fuel wood) as compared to hydrocarbons to fulfill their daily energy needs. ${ }^{3}$ Fuel wood extracted from forest is one of the most important sources of energy in the developing and under developed countries. ${ }^{4-7}$ Much of the fuel wood is now also being obtained from trees outside from forest, such as bush fellow, scrub, dead trees, pruning and lopping.

Unsystematic extraction of forest resources has alarmingly decreased the population of many woody species all across the globe. ${ }^{2,8,9}$ This has also increased the gap between resources increment and resources removal resulting in shortages and un sustainability of forest resources. ${ }^{2}$ As the availability of forest resources is inadequate, forest cover is limited and forest productivity is diminishing. Forest resource developments through various interventions need to be designed to cope with the future pressure and stop the further forest degradation. Keeping these facts in view, the present study was conducted to explore the estimates of extraction and consumption of fuel wood in rural and urban villages in eastern region (Jharkhand) of India.

\section{Material and methods}

The present study was conducted in Ranchi district of Jharkhand state, India from January, 2015 to December, 2016. The district with $5231 \mathrm{~km}^{2}$ areas is located between $23.35^{\circ} \mathrm{N}$ latitude and $85.23^{\circ} \mathrm{E}$ longitude with an average elevation of $651 \mathrm{~m}$ from mean sea level. Climate is tropical with three distinct seasons, summer, monsoon and winter. Average annual rainfall, mean minimum and maximum temperature were $1413 \mathrm{~mm}, 24^{\circ} \mathrm{C}$ and $37.2^{\circ} \mathrm{C}$, respectively. 200 households were selected following stratified random sampling procedure ${ }^{11}$ from ten villages, five each from rural and urban localities. The rural villages were inhabited by the indigenous communities only while the urban villages comprised of mixed population but majority were indigenous. Both open and close ended interview schedule along 
with first hand field observation was used for gathering information related to fuelwood consumption, type of energy sources, preferred species and source of collection. ${ }^{12}$ The survey was supplemented with participatory observations, plants identification with local names and necessary photographs for further identification.

\section{Results and discussion}

\section{Quantity, species and seasonal patterns}

Wood is the only source of domestic energy in the rural localities of the study area (Table 1) which is easily and freely available in the nearby forests due to prevailing legal rights of the indigenous community to use fuel wood from the forest.

The domestic energy need is also supplemented by cow dung in these localities but is negligible. In urban localities both wood and coal is used for domestic energy purposes with wood as major contributor (Table 1) which is either collected from non-forest woodlot, roadside plantations and scattered trees or purchased (mainly coal). The average quantity of consumption fuel material in rural localities was more than the urban localities throughout the year (Table 1). This is because of scarce availability of fuel wood in urban areas and that too is generally purchased. Changing seasons also influenced the quantity used of fuel material by the residents both in rural and urban localities. The quantity of wood and coal used for domestic fuel was higher in winter season which gradually decreased from rainy to summer season. In winter season residents used energy also for domestic heating along with cooking whereas in summer energy was used only for cooking. The daily average consumption of fuel wood per family in summer, rainy and winter season in rural localities was $6.75,8.55$ and $10.75 \mathrm{~kg}$, respectively. Similarly in urban localities coal consumption was 1.77 , 2.80 and $4.30 \mathrm{~kg}$ and fuel wood consumption was $2.84,4.81$ and 5.60 $\mathrm{kg}$ daily by a family, respectively in summer, rainy and winter season.

Sustainable utilization of forest and associated land resources is a complex issue that encompasses societal needs, ethical and cultural values, and economic status of communities. Fuelwood is renewable and its consumption can only be sustained if the rate of harvesting does not exceed the growth rate. The variety of fuelwood species used by urban population is less as compared to rural populations (Table 2) (Table 3). In total, wood of 34 species represented by 19 families were used as fuel (Table 2) (Table 3 ) of which 17 species were used by urban residents and all 34 species by rural residents (Table 2) (Table 3). In urban localities fire wood collected or purchased were represented by four species from farm land, 10 species from roadside plantations and 17 species from market (Table 3 ). In contrast fuel wood collected by rural residents were represented by six species from farm land, 12 species from roadside plantations and all 34 species from the forests (Table 2) (Table 3). Most of the fuel wood (60\%) is purchased from the markets by the urban villagers and is supplemented by collection from road side plantations $(30 \%)$ and rest from farm lands (Table $3)$. In contrast major proportion of the fuel wood demand (75\%) of the rural residents is met from the forests and rest $25 \%$ is met by collection from road side plantations.

This is because rural residents in addition to trees in their homestead and village surroundings could exploit tree species from the forest whereas urban residents used only trees of homestead and their village surroundings or roadside plantations. Moreover, rural villagers generally depend on fuel wood for these purposes as they have less access to other energy sources such as LPG, kerosene, coal etc. ${ }^{13}$ In rural areas, the only cost of fuelwood collection is physical efforts and the time taken, ${ }^{14}$ although for urban areas it is only for commercial purpose. The wood of species like Mangifera indica, Sygizium cumini, Gmelina arborea, Madhuca indica and Dalbergia sissoo were mostly used by the residents of the study area for their domestic fuel because of their availability in forest, homestead, and village surroundings as block or scattered plantations and in road side plantations also. Mangifera indica and Syzigium cumini are fruit species while Gmelina arborea and Dalbergia sissoo are common timber species. Madhuca indica is an important tree species of indigenous communities of Jharkhand as flower and fruit of this species is used to prepare local alcohol. These species are therefore abundantly planted in homesteads, village commons and as roadside plantations. Fabaceae was the most exploited family with 10 species and fortunately all these species were not in priority list of conservation as they are not threatened (Table 2). ${ }^{15}$

Table I Utilization pattern of fuel (Kg/day/family) in urban and rural villages of Jharkhand.

\begin{tabular}{|c|c|c|c|c|c|c|}
\hline \multirow{2}{*}{ Urban } & \multicolumn{2}{|c|}{ Summer season } & \multicolumn{2}{|c|}{ Rainy season } & \multicolumn{2}{|c|}{ Winter season } \\
\hline & Coal & Wood & Coal & Wood & Coal & Wood \\
\hline Namkum & 1.5 & 3.0 & 3.0 & 4.0 & 4.0 & 5.5 \\
\hline Ratu & 1.75 & 2.5 & 2.5 & 3.25 & 3.75 & 4.5 \\
\hline Ghagra & 2.0 & 2.75 & 2.75 & 3.5 & 4.25 & 5.5 \\
\hline Lalgutwa & 1.5 & 2.75 & 2.5 & 4.0 & 4.5 & 6.0 \\
\hline Ormanjhi & 2.1 & 3.2 & 3.25 & 4.5 & 5.0 & 6.5 \\
\hline Mean & 1.77 & 2.84 & 2.80 & 4.81 & 4.30 & 5.60 \\
\hline \multicolumn{7}{|l|}{ Rural } \\
\hline Rampur & 0.0 & 6.0 & 0.0 & 8.0 & 0.0 & 10.0 \\
\hline Bero & 0.0 & 6.25 & 0.0 & 7.75 & 0.0 & 9.5 \\
\hline Nagri & 0.0 & 7.5 & 0.0 & 9.0 & 0.0 & 12 \\
\hline Mandar & 0.0 & 6.75 & 0.0 & 8.5 & 0.0 & 11.5 \\
\hline Chanho & 0.0 & 7.25 & 0.0 & 9.5 & 0.0 & 10.75 \\
\hline Mean & 0.0 & 6.75 & 0.0 & 8.55 & 0.0 & 10.75 \\
\hline
\end{tabular}


Table 2 Plant species used as fuel wood in Jharkhand. ${ }^{3}$

\begin{tabular}{|c|c|c|c|c|c|c|}
\hline Scientific name & Vernacular name & Family & IS & UV & $\mathbf{R V}$ & $\mathbf{S}$ \\
\hline Shorea robusta & Sal & Dipterocarpaceae & LC & - & $\sqrt{ }$ & $\mathrm{F}$ \\
\hline Adina cordifolia & Haldu & Rubiaceae & NE & - & $\sqrt{ }$ & $\mathrm{F}$ \\
\hline Albizia odoratissima & Black Siris & Fabaceae & NE & $\sqrt{ }$ & $\sqrt{ }$ & $\mathrm{R}$ \\
\hline Acacia auriculiformis & Akashmani & Fabaceae & LC & $\sqrt{ }$ & $\sqrt{ }$ & $\mathrm{R}$ \\
\hline Acacia catechu & Khair & Fabaceae & NE & $\sqrt{ }$ & $\sqrt{ }$ & $\mathrm{R}$ \\
\hline Mangifera indica & Aam,Mango & Anacardiaceae & DD & $\sqrt{ }$ & $\sqrt{ }$ & FA \\
\hline Syzigium cumini & Jamun & Myrtaceae & NE & $\sqrt{ }$ & $\sqrt{ }$ & $\mathrm{R}$ \\
\hline Gmelinaarborea & Gamhar & Lamiaceae & NE & $\sqrt{ }$ & $\sqrt{ }$ & FA \\
\hline Cassia tora & Chakvad & Fabaceae & NE & - & $\sqrt{ }$ & $\mathrm{R}$ \\
\hline Oroxylum indicum & Manduk or Bhootvriksh & Bignoniaceae & EN & $\sqrt{ }$ & $\sqrt{ }$ & $\mathrm{R}$ \\
\hline Terminalia arjuna & Arjun & Combretaceae & NE & $\sqrt{ }$ & $\sqrt{ }$ & $\mathrm{R}$ \\
\hline Terminalia bellirica & Bahera & Combretaceae & NE & - & $\sqrt{ }$ & $\mathrm{F}$ \\
\hline Madhuca indica & Mahua & Sapotaceae & NE & $\sqrt{ }$ & $\sqrt{ }$ & FA \\
\hline Lagerostroemia parviflora & Bakli & Lythraceae & NE & - & $\sqrt{ }$ & $\mathrm{F}$ \\
\hline Dalbergia sissoo & Shisham & Fabaceae & NE & $\sqrt{ }$ & $\sqrt{ }$ & $\mathrm{R}$ \\
\hline Pongamia pinnata & Karanj & Fabaceae & LC & $\sqrt{ }$ & $\sqrt{ }$ & $\mathrm{R}, \mathrm{FA}$ \\
\hline Butea monosperma & Palas & Fabaceae & NE & - & $\sqrt{ }$ & $\mathrm{F}, \mathrm{R}$ \\
\hline Ipomoea fistula & Thethar & Convolvulaceae & NE & - & $\sqrt{ }$ & $\mathrm{F}$ \\
\hline Azadirachta indica & Neem & Meliaceae & NE & - & $\sqrt{ }$ & $\mathrm{R}, \mathrm{FA}$ \\
\hline Ficus golmerata & Gooler & Moraceae & NE & - & $\sqrt{ }$ & $\mathrm{F}$ \\
\hline Eucalyptus Sp. & Gum tree & Myrtaceae & LC & $\sqrt{ }$ & $\sqrt{ }$ & FA \\
\hline Michelia champaca & Champa & Magnoliaceae & LC & - & $\sqrt{ }$ & $\mathrm{F}$ \\
\hline Tamarindus indica & Imli & Fabaceae & $\mathrm{LC}$ & $\sqrt{ }$ & $\sqrt{ }$ & $\mathrm{R}$ \\
\hline Tectona grandis & Teak & Lamiaceae & NE & - & $\sqrt{ }$ & $\mathrm{R}, \mathrm{F}, \mathrm{FA}$ \\
\hline Cassia fistula & Amaltas & Fabaceae & NE & $\sqrt{ }$ & $\sqrt{ }$ & $\mathrm{R}, \mathrm{FA}$ \\
\hline Dalbergia latifolia & Kala shesham & Fabaceae & NT & - & $\sqrt{ }$ & $\mathrm{F}$ \\
\hline Diospyros melanoxylon & Kendu & Ebenaceae & NE & $\sqrt{ }$ & $\sqrt{ }$ & $\mathrm{F}$ \\
\hline Dillenia pentagyna & Karmal & Dilleniaceae & NE & - & $\sqrt{ }$ & $\mathrm{F}$ \\
\hline Mallotus philippensis & Sindur or Kumkum tree & Euphorbiaceae & EN & - & $\sqrt{ }$ & $\mathrm{F}$ \\
\hline Rubia cordifolia & Madder & Rubiaceae & $\mathrm{VU}$ & - & $\sqrt{ }$ & $R, F$ \\
\hline Schleichera oleosa & Kusum & Sapindaceae & EN & $\sqrt{ }$ & $\sqrt{ }$ & $\mathrm{F}$ \\
\hline Terminalia tomentosa & Asan or Saj & Combretaceae & NE & - & $\sqrt{ }$ & $\mathrm{F}$ \\
\hline Toonaciliata & Toon & Meliaceae & LC & - & $\sqrt{ }$ & $\mathrm{F}$ \\
\hline Zizyphus mauritiana & Ber & Rhamnaceae & NE & $\sqrt{ }$ & $\sqrt{ }$ & $\mathrm{R}, \mathrm{FA}$ \\
\hline
\end{tabular}

IS- IUCN status; UV- urban village; RV- rural village;VU- vulnerable; EN- endangered; NE- not evaluated; NT- near threatened; LC- least concerned; DD- Data Deficient; S: source, F-forest, R-roadside, FA-farm 
Table 3 Fuel wood collection pattern origin (in per cent) and species wise (in numbers).

\begin{tabular}{lllll}
\hline Name of area & Farm & Forest & Road side & Market \\
\hline Urban Village & 10 & 0 & 30 & 60 \\
Rural Village & 15 & 75 & 10 & 0.00 \\
Mean & 12.5 & 37.5 & 20 & 30 \\
Number of species & 4 & 0 & 10 & 17 \\
Urban Village & 6 & 34 & 12 & 0 \\
Rural Village & & & & \\
\hline
\end{tabular}

Fortunately, except five species which are vulnerable (Rubia cordifolia), near threatened (Dalbergia latifolia) and endangered (Mallotus philippinensis, Oroxylum indicum and Schleichera oleosa) all other 31 species were not in the priority list of conservation as their IUCN status is either least concerned ( 7 species) or not evaluated (22 species). Among the IUCN conservation priority species, only Oroxylum indicum and Schleichera oleosa were both used by rural and urban residents as fire wood. However, the residents of the study area used only dead trees or dried stems, branches and twigs as fuel wood from forest as was evidenced from our field observations.

An increased demand of biomass for consumptive use of rural communities has considerable impact on the forest vegetation and wildlife. ${ }^{16}$ Indiscriminate withdrawal of forest resources is the main cause of forest degradation and environmental instability. ${ }^{8,9}$ It is widely believed that wide spread use of plant biomass from forest for domestic energy by rural indigenous and urban poor population in developing tropical countries is one of the major drivers of deforestation in tropical countries causing loss of stored carbon and thereby climate change. Irrational use of natural resources has resulted in the lowering of forest quality and shortage of resources especially preferred firewood species. But looking into the species utilization pattern of fuel wood by the residents, the wide belief of deforestation due to fuel wood consumption seems to be unlikely in the study area. However, considering the exponential increase of population in the tropical countries, it is desirable to use, conserve and manage the forest sustainably for its proper utilization. Alternately, encouraging tree plantation programs of the popular species by involving the community itself in non-forest areas will also release the pressure from forest for fire wood exploitation. Institutional awareness programs to sensitize the residents are required for the species which are in need of conservation according to IUCN. Forest harvest is bioenergy which is clean, renewable energy and also is low in $\mathrm{CO}_{2}$ emissions. It is environment friendly and sustainable alternative to traditional energy. Burning wood or its product and residues has no net greenhouse gas emission because the $\mathrm{CO}_{2}$ produced is recycled by plants which absorb it for photosynthesis and cellular respiration. Wood combustion for energy saves greenhouse gas emissions which else would have been emitted by burning fossil fuels. ${ }^{18}$ Moreover such savings from wood combustion are permanent. ${ }^{17}$ Many forest related activities like collection of firewood for domestic energy instead of fossil fuel and managing forests to absorb and store more carbon can help to mitigate climate change. ${ }^{7}$ This is because the amount of carbon released through harvesting and its combustion is small compared to forest fires, other natural disturbances and fossil fuels.

\section{Conclusion}

Wood continues to be a major source of energy in the developing world and Ranchi area of Jharkhand, India is no exception. From our documentation, firewood and its species utilization pattern, it is clear that in no way firewood extraction by indigenous, rural and urban poors in our study area are causing loss to forest or threatening species to risk as they are using dead stems, twigs or branches of trees either from non-forest lands or from forest those species which are in lesser priority list of IUCN. Instead, urban poors should be capacity built for involvement in more and more afforestation/reforestation programmes of multi-purpose species in non-forest lands and their rights safeguarded so that they also use firewood solely for their domestic energy need and not supplement hydrocarbon fossils like coal. Industrialized developed world is also now considering wood as a source of clean renewable bioenergy. There should be a sustainable combination of harvest and replant. It is to recognize that woods have lighter environmental footprints and store carbon for longer periods but require sustainable management practices to lower greenhouse gas emission. It is better for the environment that the worlds demand increases for wood as energy from sustainably managed forests, plantations and woodlots rather than to rely on hydrocarbon or fossil fuels for energy.

\section{Acknowledgements}

None.

\section{Conflict of interest}

Author declares there is no conflict of interest.

\section{References}

1. Walters BB. Patterns of local wood use and cutting of Philippine mangrove forests. Economic Botany. 2005;59(1):66-76.

2. Chandra R, Soni P, Yadav V. Fuelwood, Fodder and livestock in Himalayan Watershed in Mussoorie Hills, Uttarakhand, India. Indian Forester. 2008;135(10):894-905.

3. IUCN 2017. IUCN Red List Categories.

4. Anonymous. Full fuel cycle emission factors for electricity end use from Australian Green House office. AGO factors and methods workbook. 2005. p. 43-45.

5. Reddy SB. Overcoming the energy efficiency gap in India's residential sector. Energy policy. 2003;31(11):1117-1127.

6. Lippke B, Wilson J, Meil J. Characterizing the importance of carbon stored in wood products. Wood Fibre Science. 2010;42:5-14.

7. Banyal R, Islam MA, Masoodi TH, et al. Energy status and consumption pattern in rural temperatezone of western Himalayas: a case study. Indian Forester. 2013;139(8):683-687.

8. Singh G, Rawat GS, Verma D. Comparative study of fuelwood consumption by villagers and seasonal "Dhaba owners" in the tourist affected regions of Garhwal Himalaya, India. Energy Policy. 2010;38(4):1895-1899.

9. Islam MA, Quli SMS, Rai R, et al. Forest biomass flow for fuelwood, fodder and timber security among tribal communities of Jharkhand. Journal of Environmental Biology. 2015;36(1):221-228. 
10. Ray GL, Mondol S. Research methods in social sciences and extension education. India: Kalyani Publishers; 2004.

11. Chettri N, Sharma E, Deb DC, et al. Effect of firewood extraction on tree structure, regeneration and woody biomass productivity in a trekking corridor of the Sikkim Himalaya. Mountain Research and Development. 2002;22(2):150-158.

12. Bijalwan A, Sharma CM, Kediyal VK. Socioeconomic status and livelihood support through traditional agroforestry systems in hill and mountain agroecosystem of Garhwal Himalaya, India. Indian Forester. 2011;138(12):1423-1430.

13. National Sample Survey Organization (NSSO) (2007-08)-Survey Report, Ministry of Statistics \& Programme Implementation (MOSPI), Government of India.
14. Miner R, Lucier A. A value chain assessment of climate change and energy issues affecting the global forest based industry. 2004.

15. IPCC. Good practice guidance for land use, land use change and forestry. India: Institute for Global Environmental Strategies (IGES); 2003.

16. Chakravarty S, Puri A, Subba M, et al. Mitigate climate change and use processed or value added harvested wood products. In: Sharangi AB, Datta S, editors. Value addition of Horticultural Crops: Recent Trends and Future Directions. Germany: Springer; 2015. p. 245-268.

17. Mukherjee N. Participatory rural appraisal: methodology and applications. India: Concept Publishing Company; 1993.

18. Centre for Monitoring Indian Economy (CMIE). India's Energy Sector India: Centre for Monitoring Indian Economy; 2001. 